\title{
Kurrikulumontwikkeling vir Spraak-Taalterapie en Oudiologie: Basis en Beginsels
}

\author{
S.R. Hugo, D. Phil (Pretoria) \\ I.C. Uys, D. Phil (Pretoria) \\ Departement Spraakheelkunde en Oudiologie, \\ Universiteit van Pretoria
}

\begin{abstract}
OPSOMMING

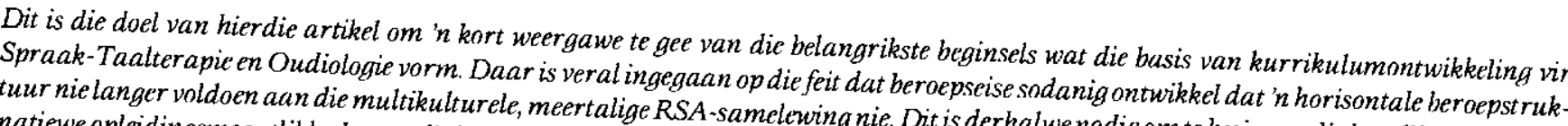
natiewe opleidingsmoontlikhede soos diploma-opleiding vir tegnici, sertifikaatprogramme vir gemeens ap tesin oor die instelling van altergerigte magisteropleiding. In samehang hiermee het beroepsfunksies só uitotprogramme vir gemeenskapsrehabilitasiewerkers en beroepsgemeenskapsdiens en konsultasie 'n veel groter rol in die kurrikulum behoort te spspekte soos rekenaargeletterdheid, bestuursfunksies,
\end{abstract}

\section{ABSTRACT}

The aim of this article is to discuss some of the important issues that form the basis of curriculum development for education in speech. language therapy and audiology. The demands of the profession are such that a horizontal occupational structure is no longer adequate in needs. These may include diploma training for techniciore necessary to investigate alternative educational options to accommodate current directed masters courses. It is also apparent that the professional function prammes for community rehabilitation workers and professionally the point where aspects such as computer literacy, management functions of the speech-language therapist and audiologist have extended to curriculum than is the case at present.

\section{INLEIDING}

Wém We must take the initiative in making things happen for us, rather (Cole, 1986: 42).

Hierdie stelling is verteenwoordigend van die algemene gee wat tans in die beroep van Spraakheelkunde en Oudiologie heers. Dit is egter ook tekenend van twee ander belangrike kontekse, te wete die universiteitswese in die algemeen en die Suider-Afrikaanse samelewing in die besonder. Teen en die raamwerk is dit seker nie vreemd dat die behoefte van kurriku lumontwikkeling vir die opleiding van spraak-taalterapeute en oudioloë so sterk na vore gekom het nie.

Die fundamentele vraag wat beantwoord moet word is: wat is die spesifieke beroeps- en opleidingsveranderinge wat in 'n opleidingskurrikulum vervat moet word?

\section{KURRIKULERINGSVERANDERINGE: INTER- NASIONALE GESIGSPUNTE}

Literatuur van die 1980-1990 dekade word gekenmerk deur kritiese evaluasie van sowel die beroep as die bestaande opleiding. Dit is veral ASHA wat deur middel van omnibusopnames data oor die stand van spraakterapie en oudiologie as beroep ingesamel het. Die opleiding is dan geëvalueer in terme van die

Die Suid-Afrikaanse Tydskrif vir Kommunikasieafwykings, Vol. 37, 1990 beroepseise. Sodoende is verskeie voorgraadse en nagraadse kursusse, asook voortgesette onderrig geweeg in terme van relevansie van 'n ontwikkelende en veranderende beroep (Hyman, 1986; Shewan, 1988; Terrizzi, 1988). Uit die Britse literatuur blyk dit ook dat oplossings vir diensleweringsprobleme gevind kan word deur die behoefte aan diens en die voorsiening van diens vas te stel (Enderby \& Davies, 1989).

Relevante demografiese gegewens in verband met die stand van die beroep dui op klemverskuiwings wat leemtes met betrekking tot beroeps- en bestuursfunksies laat. Dit is veral die internasionale menseregteverdrae en die standpunte van die Wèreld Gesondheidsorganisasie wat nuwe insigte gebring en oriëntasieveranderinge laat plaasvind het.

Opsommenderwys kan die volgende riglyne vir verandering aangestip word:

* Vir ongeveer twee dekades word die behoefte aan spraak terapie en oudiologie as 'n enkel-professie bepleit (Feldman, 1981). Alhoewel daar geleidelike verandering in die opleidingsprogramme te bespeur is, is die algemene tendens vir die VSA steeds om eerder as oudioloog of spraakterapeut te kwalifiseer, te registreer en te werk. Demografiese bevindings dui egter aan dat die gevallebelading in die praktyk deskundigheid op beide gebiede vereis en noop die aanvaarding van stellings soos: "True specialization grows 
out of generalist training" (Feldman, 1981: 942).

* Daar is vir baie jare reeds 'n behoefte om 'n beroepskorps daar te stel wat Spraakterapie en Oudiologie tot 'n onafhanklike beroep kan lei. Alhoewel die oorgrote meerderheid spraakterapeute en oudioloë steeds by instansies soos skole en hospitale diens lewer, is daar tans 'n omskakeling na privaat praktyk te bespeur (Shewan, 1988). Hierdie oorskuiwing word deur ASHA ondersteun maar hulle beklemtoon ook die feit dat opleiding hierby aangepas moet word.

* Verwant aan die bogemelde punt, is 'n behoefte dat spraakterapeute en oudioloë onmiddellik na opleiding (met toetrede tot die beroepslewe) oor al die nodige beroeps- en bestuursvaardighede sal beskik om onafhanklik en toerekenbaar in die privaat praktyk op te tree. Opleidingsprogramme moet dus voorsiening maak dat studente daardie kritiese korpus van kennis en vaardighede bekom voor toetrede tot die beroep (Feldman, 1981; Lingwall, 1988).

* Juis as gevolg van die veranderende werksomstandighede het dit nodig geword om spraakterapeute en oudioloë vakinhoudelik meer omvangryk voor te berei op hulle beroepsfunksies (Flower, 1984). In die basiese opleiding moet aandag geskenk word aan die kwantiteit en kwaliteit van die teoretiese en kliniese opleiding, die verhouding tussen fundamentele geesteswetenskaplike en natuurwetenskaplike inhoude; die verhouding tussen basiese en toegepaste wetenskappe; die verhouding tussen akademiesteoretiese en kliniese opleiding (Terrizzi, 1988).

* Feldman (1981) identifiseer die behoefte aan voortgesette onderrig en veral kliniese magistergrade en doktorsgrade. Opleidingsinstansies moet ook voortgesette onderrig aan oudstudente, wat nie noodwendig graad-kwalifikasies is nie, as 'n verpligting beskou omdat die vakgebied so vinnig ontwikkel (Hyman, 1986; Shewan, 1988).

* Een van die grootste behoeftes wat deur verskeie ondersoeke geidentifiseer is, is die onkunde oor bestuursfunksies wat tans by spraakterapeute en oudioloë bestaan (Foxman, 1988; Gelatt, 1988; Griffin, 1988; Holley, 1988). Die aanbeveling word gemaak dat veral die bemarking van dienste aandag moet geniet, omdat dit al hoe meer deel word van die eise wat aan lewensvatbare beroepe gestel word.

* Verskeie behoeftes het ontstaan as gevolg van politieke druk in samehang met tegnologiese ontwikkeling. Die belangrikste hiervan is:

- Die behoefte aan rekenaargeletterdheid.

Die rekenaar word al hoe meer onontbeerlik in die beoefening van spraakterapie en oudiologie. Gedurende 1984 het ongeveer $27 \%$ spraak-taalterapeute en oudioloë rekenaars gebruik; en 'n opname in 1988 dui op 'n styging na amper $58 \%$. Dit is interessant dat die reke- naar in 1986 hoofsaaklik virbestuursfunksies (administrasie, rekordhouding en woordverwerking) aangewend is, terwyl die 1988-opname aantoon dat rekenaars tans hoofsaaklik vir diagnostiese en behandelingsdoeleindes gebruik word. Opleiding in rekenaargebruik word derhalwe al hoe meer 'n noodsaaklikheid (Hyman, 1986; Shewan, 1988).

- Die betrokkenheid by minderheidsgroepe.
Reeds in 1985 het ASHA dic standpunt ingeneem dat hulp verleen behoort te word aan persone in uiteenlopende sosiale, kulturele, ekonomiese en linguistiese populasies. Alhoewel opleiding van terapeute uit minderheidsgroepe vanaf 1987 spesiale aandag geniet, is daar huidiglik in die VSA slegs $3 \%$ geregistreerde spraaktaalterapeute en oudioloè uit hierdie bevolkingsgroepe. Opnames toon egter dat terapeute al hoe meer betrokke raak by die hantering van minderheidsgroepe (Cole en Massey, 1985; Hyman, 1986; Shewan, 1988).

- Die betrokkenheid by spesiale groepe as gevolg van die ontwikkeling van die wetenskap.

As gevolg van die identifikasie van kommunikasieafwykings by spesifieke groepe soos taalleergestremdes, Vigslyers, verskeie neuropatologieë en selfs bejaardes (met die toename in hierdie populasie), brei die spraakterapeut en oudioloog se werksomvang skielik uit. $\mathrm{Op}^{-}$ leidingsinstansies moet derhalwe voorsiening maak vir die voortgesette onderrig van persone wat in die verlede gekwalifiseer het ten einde hulle vaardighede na die nuwe toepassingsvelde uit te brei.

\section{KURRIKULERINGSVERANDERINGE: NASIONALE VERTREKPUNTE}

Dit is opmerklik dat die plaaslike literatuur ' $n$ byna identiese weerspieèling van oorsese veranderinge aandui. Dit is egter te verstane omdat die VSA-model vir baie dekades al aangepas en toegepas is in die RSA. Juis hierdic basis behoort in 'n evaluasie van bestaande opleiding bevraagteken te word. Soos Delaney en Malan (1984:75) dit stel: "This foreign model has been modified to provide our South African model. This is not to say that a foreign model modified on the basis of limited information is necessarily inadequate, but rather that it is important that we be aware that this is the situation."

'n Eiesoortige probleemsituasie dra by tot die noodsaaklikheid van 'n RSA-opleidingsmodel. Ten eerste is dit die kenmerke van die ontwikkelende land wat eiesoortige aanpassings vir dienslewering en opleiding noodsaak. Penn (1986) bevraagteken die relevansie van opleiding in hierdie omstandighede, omdat daar tans 'n "ongesonde status en beeld van die beroep as oorwegend 'n luukse bestaan" (Uys, 1987). In samehang hiermee bepleit Aron (1984(a) en 1987) veranderinge in opleiding en dienslewering om aan hierdie behoeftes van, onder andere, minderbevoorregting, armoede, onkunde en selfs ongeletterdheid te voldoen, deur alternatiewe opleiding binne die raamwerk van gemeenskapsgebaseerde benaderings aan te bied. Sy staan ook die opleiding van primêre sorgpersone voor. Fourie (1984) ondersteun hierdie siening dat aanpassing by die eise van 'n Derde Wêreldland die opleiding en aanstelling van semigekwalifiseerde persone onder toesig noodsaak. Daarenteen meen Morgan, Geraghty, Dawber, Motshei, Drew, Motshei en Segal (1984) dat 'n gemeenskapsoriëntasie nie aan 'n afs. nderlike kursus, of ' $n$ afsonderlike groep werkers met anc er funksies toegesê behoort te word nie, maar dat'n gemeenskapsoriëntasie geïnkorporeer behoort te word in die opleiding van spraakterapeute en oudioloë.

Die implikasies van hierdie voorstelle is eerstens dat die tradisionele benadering tot opleiding (die identifikásie van patologie in die individu en die rehabilitasie ván die idividu) en dienslewering (die uitvoering van die praktyk binne die raamwerk van institusionele strukture, bv. hospitale, skole, ens.) ontoepaslik is. Voorbereiding van die spraakterapeut en 
oudioloog om by toetrede tot die praktyk onafhanklik toerekenbare diens te lewer, plaas 'n hoë premie op opleiding veral met betrekking tot omvattende primêre, sekondêre en tersiêre voorkoming en konsultasie (Uys, 1985).

Die tweede implikasie is dat spraakterapeute en oudioloë ' $n$ navorsingsinset sal moet lewer en dus 'n sterker akademiese opleiding in wetenskapmetodologie sal moet ontvang om hulle voor te berei op sinvolle navorsing (Uys, 1986; 1987).

'n Kompliserende faktor wat die eise van 'n onwikkelende land verder verhoog is die geografiese kenmerke van die RSA. Die uitgestrektheid van plattelandse gebiede en die groot bevolkingsamevloeiing ver van sentrale gebiede is vroeg al as 'n besondere kenmerk van dienslewering geïdentifiseer. Reeds in 1966 onderstreep Pienaar die behoefte aan "properly conducted surveys at regular intervals over large areas" en "clinics, mobile and otherwise established in ... country districts" (in Morgan et al. 1984: 111). In opleiding stel dit die eis dat klem gelê moet word op gemeenskapsdiens, konsultasie, en veel eerder generalisasie as spesialisasie.

Noodwendig hang geografiese kenmerke nou saam met die beskikbaarheid van dienste. In 1984 was daar na beraming reeds 'n tekort aan 4,494 spraakterapeute en oudioloë in die RSA (Fourie, 1984). In 1986 het die tekort gestyg tot oor die 5000 en volgens projeksie (met inagneming van die bevolkingsgroei) sal daar in 2000 'n tekort aan minstens 10000 wees (Gestremdheid in die Republiek van Suid-Afrika, 1987(a),(b), (c)). Dit het verder aan die lig gekom dat bykans alle dienste uitsluitlik gerig is op die identifikasie, diagnose en behandeling van bevoorregte, stedelike blankes, dat dienste aan die ontwikkelende plattelandse bevolkingsgroepe totaal ontoereikend is en dat voorkomingsdienste feitlik nêrens beskikbaar is nie (Gestremdheid in die Republiek van Suid-Afrika, 1987(c); Aron, 1984(a)).

Verskeie aanbevelings is reeds gemaak om hierdie probleem te oorkom, naamlik:

- Dié verhoging van studentetalle uit alle bevolkingsgroepe by bestaande opleidingsinstansies (Uys, 1984).

- Die instelling van opleidingskursusse by ander (addisionele) universiteite, met verál die oog op opleiding van persone uit Asiër- Kleurling- en Swart-bevolkingsgroepe. Daar is tans ongeveer 4 Kleurling-. 25 Asiër- en 4 Swartspraakterapeute en oudioloè geregistreer (Gestremdheid in die Republiek van Suid-Afrika, 1987(c)). Met inagneming van die bevolkingstoename van hierdie drie groepe, is die opleiding van spraakterapeute en oudioloë uit hierdie groepe noodsaaklik (Pènn, 1986; Crossley, 1987).

- Die aanpassing van opleidingskursusse met die oog daarop om terapeute in staat te stel om groter pasiëntgetalle te hanteer deur alternatiewe spraakterapeutiese en oudiologiese benadering (Morgan et al. 1984; Hugo \& Louw, 1987). konsultasie (Uys, 1985) en die gebruik van ondèrsteuningsdienste (Enderby \& Davies, 1989).

Die multikulturele, vecltalige bevolkings van die RSA skep 'n behoefte in terme van die omvang en kwaliteit van die bestaande dienste. Die opleiding en kwalifikasies van spraakterapteute en oudioloë kan, met spesiale verwysing na hulle rol in 'n meertalige, multikulturele gemeenskap, gekritiseer word. Die opleiding voldoen huidiglik beslis nie aan al die eise wat deur hierdie samelewing gestel word nie (Uys, 1984). Die habilitasie en rehabilitasie van kommunikasieafwykings is anders as ander terapieë in die opsig dat kommunikasie beide die middel en die doel in behandeling is. Die spraakterapeut en oudioloog moet nie slegs oor'n diepgaande kennis van die taal van die pasiënt beskik nie, maar ook 'n goeie begrip van die sosiokulturele eienskappe van die betrokke bevolkingsgroep hê (Aron, 1984 (b); Crossley, 1984).

Verskeie voorstelle word voorgehou ter oplossing van hierdie probleem:

- Om basiese konsepte van Swart- en Indiërtale in te sluit in die opleiding van spraakterapeute en oudioloë.

- Om inligting in verband met sosiokulturele verskille in te sluit in die opleiding van spraakterapeute en oudioloë (Crossley, 1984; Segal \& Drew, 1984).

- Om in spanverband navorsing te doen oor hierdie verskille en verskynsels, sodat norme vir kommunikasiegedrag op alle vlakke vasgestel, en diagnostiese en behandelingsmateriaal ontwikkel kan word (Aron, 1987; Webb, 1984).

- Om van spraakterapie- en oudiologie-assistente, of tolke gebruik te maak in dienslewering (Uys, 1984).

- Om spraakterapeute en oudioloë vanuit hierdie groepe op te lei (Penn, 1986).

Hierdie behoefte aan verandering, om opleiding en dienslewering aan te pas by die RSA-konteks, is ook reeds deur die outeurs geïdentifiseer in 'n navorsingsprojek. Dit blyk uit vraelyste wat aan 'n verteenwoordigende populasie van spraak-taal-gehoorterapeute gestuur is, asook uit onderhoude wat met die persone gevoer is, dat $73 \%$ aanpassing van die opleiding by RSA-omstandighede voorstaan, terwyl $62 \%$ voorstanders is van verandering in opleiding om voorsiening te mak vir klemverskuiwing met betrekking tot die beroepsfunksies (Hugo \& Uys, 1988).

Die voorafgaande inligting skets op 'n gekondenseerde wyse enkele van die vraagstukke rondom opleiding en meer spesifiek die probleem van kurrikulering vir spraakterapie en oudiologie. Indien dit die probleem is - wat is die oplossings?

\section{TENTATIEWE OPLOSSINGS VIR KURRIKULUMS}

Kurrikulumontwikkeling is die "doelgerigte en sistematiese opbou van die kurrikulum en die voortdurende evaluering, herevaluering en vernuwing daarvan" (Kachelhoffer, 1987: 14). Indien die inligting in die voorafgaande paragrawe as vertrekpunt gebruik word, is dit duidelik dat die bestaande opleiding van spraak-taalterapeute en oudioloë in die RSA redelik indringend verander moet word. Hierdie veranderinge sal natuurlik ook in samehang met die eiesoortige karak. ter van die inrigting waar die opleiding aangebied word, moet on twikkel. Daar is egter twee belangrike fundamentele aspekte wat as basies tot enige kurrikulumontwikkeling gesien kan word.

\section{Die beroepstruktuur en opleiding}

Ten eerste is dit vir die internasionale aanvaarding van beroepsbeoefenaars belangrik dat die aard en kwaliteit van opleiding sodanig sal wees dat professionele erkenning maklik 
plaasvind en uitruiling van studente 'n praktiese moontlikheid sal wees. Derhalwe is 'n vierjarige beroepsgerigte baccalaureusgraad met hoofvakke Spraak-'Taalpatologie en Oudiologie 'n minimum vereiste vir registrasie as spraakterapeut en oudioloog. Dit kan dan gevolg word met 'n magister- en doktorsgraad vir bykomende kwalifikasie en spesialisasie.

'n Ander vorm van professionele graadopleiding vir registrasiedoeleindes moet egter oorweeg word. Dit is die moontlikheid van 'n twee- of driejarige, beroepsgerigte magistergraad in Spraak-'Taalpatologie of Oudiologie, met as voorvereiste enige algemene baccalaureusgraad. Hierdie opleiding sou 'n verintensifisering van die basiese opleiding beteken met gevolglike registrasie as ò spraakterapeut òf oudioloog. Die voordeel van sodanige opleiding is dat dit volwasse en gemotiveerde studente sal lok wat waarskynlik uit 'n spesifieke beroepsopset (bv. skole vir gehoorgestremdes of serebraalgestremdes), 'n spesifieke belangstelling in die kommunikasiegestremde ontwikkel het.

Ten tweede is dit so dat omstandighede in die RSA dui op die ondervoorsiening van dienste in die algemeen, maar spesifiek ook met betrekking tot diens aan ander kultuurgroepe, ander taalgroepe, die geriatriese en die plattelandse bevolking. Dit is derhalwe duidelik dat die verhoging van basiese graadopleiding alleen nie die antwoord op hierdie probleem sal wees nie. Die oplossing hiervoor is die instelling van ander vorms van diens wat dienooreenkomstig ander tipes van opleiding benodig. Dit word visueel voorgestel in Figuur 1, en bestaan in essensie uit die volgende:

- graadopleiding aangebied deur universiteite vir die kwalifikasie van terapeute wat kan optree as probleemoplossers, toesighouers, konsultante en spesialiste.

- diploma-opleiding aangebied deur technikons vir die kwalifikasie van terapeutiese assistente en spraak- en gehoorgemeenskapswerkers wat gemoeid sal wees met die aanbieding van roetine/tegniese aspekte van kommunikasiepatologie.

- sertifikaatprogramme aangebied deur diensleweringsorganisasies vir die kwalifikasie van gemeenskapsrehabilitasiewerkers.

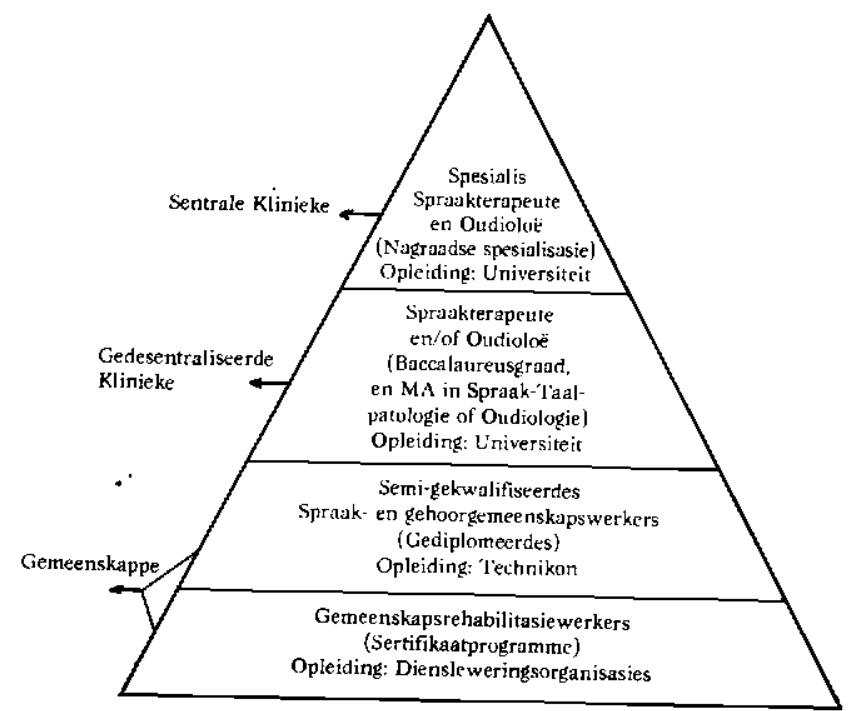

Figuur 1: Opleidingsmodel vir die beroepstruktuur

\section{Kurrikulering en beroepsfunksies}

Wanneer die jaarboeke van opleidingsinstansies bestudeer word, is dit duidelik dat opleiding by universiteite tans grootliks 'n afwykinggerigte (bv. hakkel, breinbesering, ens.) benadering volg. Dit beteken dat hoofsaaklik twee van die beroepsfunksies, diagnose en terapie, uitvoerig onderrig word, dikwels ten koste van die meeste ander beroepsfunksies. Die resultaat hiervan is 'n onewewigtige kurrikulum wat nie met die huidige beroepseise tred hou nie.

Ten einde 'n kurrikulum te ontwikkel wat 'n funksionele holistiese basis het, is dit nodig om alle beroepsfunksies te lys en te definieer. Hierdie funksies word in Tabel 1 uiteengesit.

Tabel 1: Beroepsfunksies van spraak-taalterapeute en oudioloë

\section{BEROEPSFUNKSIE OMSKRYWING}

1 Sifting

Aktiwiteite wat uitgevoer word ten einde uit'n groot populasie te differensieer tussen persone wat normale kommunikasie het en diegene wat vollediger bestudeer moet word om vas te stel of hulle 'n spesifieke afwyking het.

2 Voorkoming Aktiwiteite wat uitgevoer word ten einde die aanvang, ontwikkeling en komplikasie van 'n kommunikasieafwyking te elimineer en/of te inhibeer.

3 Gemeenskapswerk Aktiwiteite wat daarop gerig is om 'n diens aan en deur die gemeenskap te lewer ten einde kommunikasieafwykings te voorkom, te diagnoseer en te behandel.

4 Terapie

Aktiwiteite wat poog om kommunikasiegedrag te modifieer. Hier kan drie tipes aktiwiteite onderskei word:

* gerig op verwerking van elemente van normale kommunikasie

* gerig op verwerwing van kompensatoriese prosedures in gevalle van onherstelbare afwykings

* gerigop verandering van weerstand teen kommunikasieverbetering.

5 Evaluasie

Aktiwiteite wat ten doel het om 'n kommunikasie-afwyking te beskryf of om beslissings aangaande hulpverlening te maak. Die doel hiervan is:

* om aanwesigheid en graad van af wyking te bepaal

* om die afwyking te beskryf

* om die stappe ter oplossing aan te dui

* om verwysingsraamwerk vir intervensiegevolge te stel (prognose)

* om aan ander prófessies die implikasies van die afwyking aan te toon. 
Tabel 1 Vervolg

\begin{tabular}{|c|c|}
\hline 6 Beraad & $\begin{array}{l}\text { Dienste gebied aan die kommunikasie- } \\
\text { afwykende en/of sy familie (en belang- } \\
\text { rike omgewingsindividue) gerig op die } \\
\text { oplossing of vermindering van pro- } \\
\text { bleme wat met die kommunikasieaf- } \\
\text { wyking verband hou of daaruit spruit. } \\
\text { Hierdie dienste vul terapie aan ten op- } \\
\text { sigte van: } \\
\text { * beraad aan die kommunikasieaf- } \\
\text { wykende om ander vorms van pro- } \\
\text { fessionele hulp te soek en te aanvaar } \\
\text { * beraad aan familielede ten einde } \\
\text { terapie te steun en hulle kommuni- } \\
\text { katiewe rol aan te dui. }\end{array}$ \\
\hline 7 Bestuur & $\begin{array}{l}\text { Aktiwiteite wat uitgevoer word om } \\
\text { menslike finansiële, fisiese en inlig- } \\
\text { tingshulpbronne te benut ten einde die } \\
\text { onderneming (ondernemings wat met } \\
\text { die kommunikasieafwykende gemoeid } \\
\text { is) se doelwitte aan te wend. Ditsluit in } \\
\text { bestuurfunksies soos beplanning, or- } \\
\text { ganisasie, koördinering en beheer. }\end{array}$ \\
\hline 8 Konsultasie & $\begin{array}{l}\text { Aktiwiteite wat daarop gerig is om aan } \\
\text { ander professionele persone 'n diens te } \\
\text { lewer ten bate van die kommunika- } \\
\text { sieafwykende. }\end{array}$ \\
\hline 9 Navorsing & $\begin{array}{l}\text { Aktiwiteite wat daarop gerig is om tot } \\
\text { grondige en akkurate kennis en insig } \\
\text { van normale en afwykende menslike } \\
\text { kommunikasie te kom. }\end{array}$ \\
\hline 10 Onderrig & $\begin{array}{l}\text { Die opleiding en opvoeding van per- } \\
\text { sone in normale en afwykende mens- } \\
\text { like kommunikasie in terme van ken- } \\
\text { nis, vaardighede en gesindhede wat } \\
\text { daarmee verband hou. }\end{array}$ \\
\hline
\end{tabular}

In 'Tabel 1 is gepoog om alle beroepsfunksies, ongeag die spesifieke arbeidsterrein, en toepaslik op sowel spraakterapeute as oudioloë, uit te spel. Uiteindelik sal dit noodwendig van die spesifieke werkgewer en werksomstandighede afhang watter funksie/s die meeste beklemtoon word, maar vir kurrikulumontwikkeling is dit nodig om alle fasette in die sillabus te betrek.

Beroepstruktuur en beroepsfunksies

Aangesien die voorgestelde beroepstruktuur, sowel as die gedifferensieerde opleiding van verskeie faktore afhanklik is, kan daar tans slegs pro-aktiewe voorstelle gemaak word oor die versoening tussen opleiding, struktuur en funksies.

Alhoewel dit met die eerste oogopslag mag voorkom asof alle kurrikulums slegs swaarder gelaai word met vakinhoud, is dit glad nie die geval nie. Grondliggend aan die opleiding is andersoortige opleidingsoriëntasies en opleidingsmetodieke. Klemverskuiwing met betrekking tot die gewig van insette oor die funksies sal die verskillende struktuurvlakke onderskei. Dit word aanvaar dat al die funksies in'n meerdere of mindere mate op elke beroepsvlak ter sprake moet kom. Basiese riglyne kan egter voorgestel word. Basisvlakwerkers sal waarskynlik beperkte kennis en vaardigheid met betrekking tot sekere van die funksies (bv. sifting, behandeling, voorkoming ens.) benodig. Die eerste kwalifikasie in Spraak-Taalterapie en Oudiologie sal daarenteen weer 'n algemeen gemiddelde kennis en vaardigheid met betrekking tot alle funksies as voorvereiste stel. Namatestyging in die hiërargie plaasvind, kan'n stygende tendens in indiepte-kennis met betrekking tot bestuur, konsultasie, onderrig ens. 'n voorvereiste wees, terwyl spesialisasie deur navorsing, 'n getande profiel aan opleidingsomvang kan verskaf.

\section{KURRIKULUM QUO VADIS?}

Alles is al vantevore bedink. Die noodsaak is weer daaraan te dink. Dit is 'n algemeen geldige stelling.

Die voorafgaande bespreking lig enkele belangrike tendense uit waarvoor toegelaat moet word in kurrikulumontwikkeling. Kurrikulumontwikkeling is egter nie 'n horisontale groei nie maar vind veelvlakkig plaas. Op die makrovlak sal daadwerklik gekyk moet word na die verskillende vlakke van opleiding (insluitend technikons en diensleweringsinstansies) sodat mindere en andersoortige kwalifikasies as voorvereiste vir omvattender en meer koste-effektiewe dienslewering daargestel kan word.

Mesovlakverandering betrek die spesifieke departemente en sluit in kursuskurrikulering. Hier is dit essensieel dat die onderskeie departemente kursusse ontwikkel wat eerstens aan die universele behoeftes van die beroep voldoen, maar tweedens toelaat vir die spesifieke karakter van die bepaalde universiteit en die geografiese gemeenskap wat die universiteit bedien. Daar moet veral ook aandag gegee word aan die rol wat nagraadse onderrig, ondersteuningsprogramme en voortgesette onderrig binne die breë kursuskurrikulum speel.

Wat die mikrovlak betref, moet volledig besin word oor silla bustemas, en lesingeenhede, maar sinvolle beplanning hier sal van waarde wees indien dit in samehang met onderrigdidaktiek en personeelorganisasie gedoen word.

Die uiteindelike sukses van kurrikulumontwikkeling is in die laaste instansie in die hande van diegene wat die onderrig moet aanbied. Dit beteken dat hoë eise aan dosente en ander opleiers gestel sal word. Van hulle sal kwaliteite vereis word soos aanpasbaarheid, deeglike vakkennis, hoë intelligensie, entoesiasme, bereidwilligheid om te leer en te groei, en selfs enkele nie-vakverwante vaardighede en gesindhede.

Hierdie vereiste eienskappe is in elk geval kenmerkend van toegewyde en professionele spraakterapeute en oudioloë. Daar is derhalwe geen twyfel nie dat die beroepslui met gemak sal kan voldoen aan die uitdagings wat kurrikulumontwikkeling stel.

\section{VERWYSINGS}

Aron, M.L. Introduction. In M.L. Aron en L. le Roux (Reds) Proceedings of the Conference on Community Work in Speech and Hearing Therapu. SAVSG, 1-5, 1984(a).

Aron, M.I. Community work in Specch Therapy. In S.M. Beukes (Red.) Simposiumreferate: Die Rol van die Spraakterapeut in 'n Meertalige Samelewing. Universiteit van Pretoria, 10-16, 1984(b). 
Aron, M.L. Community-based rehabilitation for communication dis orders. In W. Smit en S. Meyer (Reds.) Nasionale Konferensicverrigtinge. SAVSG (ongenommer), 1987.

Cole, P.R.I want to shape my own future. How about you? $A S H A$ 28(a), 41-42, 1986

Cole, L. en Massey, A. Minority student enrolment in higher education institutions with communicative disorders programs. ASHA, 27(6), 33-37, 1985

Crossley, S. Language remediation in an Indian community. In S.M. Beukes (Red.) Simposiumreferate: Die Rol van die Spraakterapeut in ' $n$ Meertalige Samelewing. Universiteit van Pretoria, 38-61, 1984

Crossley, S. How to train clinicians to work with culturally different clients. Communiphon, 280, 2-11, Nov./Des. 1987.

Delaney, C. en Malan, K. Community speech and hearing therapy: some questions before answers. In M.L. Aron en L. Ie Roux (Reds.) Proceedings of the Conference on Community work in Speech and Hearing Therapy. SAVSG, 73-84, 1984

Enderby, P. en Davies, P. Communication disorders: Planning a service to meet the needs. British Journal of Disorders of Communication, 24, 301-331, 1989.

Fcldman, A.S. The challenge of autonomy. ASHA, 23(12), 941$945,1981$.

Flower, R.M. Delivery of Speech-Language Pathology and Audiology Services. Baltimore: Williams en Wilkens, 1984.

Fouric, H.P. Maatskaplike behoeftebepaling. In S.M. Beukes (Red.) Simposium-Referate: dic Rol van die Spraakterapeut in 'n Meertalige Samelewing. Universiteit van Pretoria, 2-9, 1984.

Foxman, C.A. Speak with sense. ASHA, 30(9), 46-47, 1988.

Gelatt, P.J. The business of grantseeking. ASHA, 30(9), 43-45, 1988.

Gestremdheid in die Republiek van Suid-Afrika: Hoofversla 1 1. Pretoria: Departement van Gesondheid en Bevolkingsontwikkeling, 1987(a).

Gestremdheid in die Republiek van Suid-Afrika: Gehoorgestremaheid 8, Pretoria: Departement van Gesondheid en Bevolkingsontwikkeling, 1987(b)

Gestremdheid in die Republiek van Suid-Afrika: Spraakgestremdheid 10, Pretoria: Departement van Gesondheid en Bevolkingsontwikkeling, 1987 (c).

Griffin, K.M. Quality sells, ASHA, 30(9),48-51, 1988

Holley, S.C. President's page ASHA, 30 (9), 37-38, 1988.

Hugo, S.R. en Louw, B. Ouergesentreerde interaksieterapie. In W.
Smit en S. Meyer (Reds.) Nasionale Konferensic-Verrigtinge. SAVSG, (ongenommer), 1987.

Hugo, S.R. en Uys, I.C. Kurrikulering van spraakheelkunde en oudiologie. In Referate aelewer tudens die Oudiolospirkmare's. SAVSG 190-201, 1988.

Hyman, C.S. The 1985-omnibus survey. Implications for strategic planning. ASHA, 28(4), 19-22, 1986.

Kachelhoffer, P.M. Kurrikulumontwikkeling: riglyne aan kurrikulumkomitees. UP-Dosent, (1), 14-20, 1987

Lingwall, J.B. Report: Evaluation of the requirements for the certificates of clinical competence in speech-language pathology and audiology. ASHA, 30(9), 75-78, 1988.

Morgan, R., Geraghty, S., Dawber, A., Motshei, F., Drew, M., Motshei. M. en Segal, D. An alternative approach to speech therapy. In M.L. Aron en I. le Roux (Reds.) Procedings of the Conference on Community Work in Spech and Hearing Therapy. SAVSG, 110 120, 1984.

Penn; C. Guest Editorial. Communiphon, 274:2, 1986

Segal, DF. en Drew, M. Argument for a community oriented a pproach to language therapy. In S.M. Beukes (Red.) Simposiumreferate: Die Rol van die Spraakterapeut in 'n Mecrtalige Samelewing. Universiteit van Pretoria, 88-92, 1984.

Shewan, C.M. 1988-Omnibussurvey: Adaptation and progress in times of change. $A S H A .30(8), 27-32,1988$.

Terrizzi, A.M. Status report on undergraduate education in com munication sciences and disorders. ASHA, 30\{5), 31-33, 1988.

Uys, I.C. Spraak- en gehoorheelkunde in 'n meertalige samelewing. In S.M. Beukes (Red.) Simposiumreferate: Dic Rol van die Spraakterapeut in 'n Meertalige Sameweling: Universiteit van Pretoria, 88.93, 1984.

Uys, I.C. 'n Medekonsult asiemodel vir spraak- en gehoorterapie in die RSA. In I.S. Hay en I.C. Uys'Taalverskeidenheid en Taalpatologit' Pretoria: Universiteit van Pretoria, 1985.

Uys, 1.C. Gas Redaksioneel. Communiphon. 280, 1-2, 1986.

Uys, I.C. Navorsing: 'n diens aan en deur die klinikus. In W. Smit en S. Meyer (Reds.) Nasionale Konferensie-Verrigtinge. SAVSG, (on genommer), 1987.

Webb, V.N. Sosiolinguistiek en die spraakterapie. In S.M. Beukes (Red.) Simposiumreferate: Dic rol van dic Spraakteraprut in in Mertalige Samelewing. Universiteit van Pretoria, 23-27, 1984 


\section{INFORMATION FOR CONTRIBUTORS}

The South African Journal of Communication Iisorders publishes reports and papers concerned with research, or critically evaluative theoretical, or therapeutic issues dealing with disorders of speech, voice, hearing or language, or on aspects of the processes underlying these.

The South African Journal of Communication IDisorders will not accept material which has been published elsewhere or that is currently under review by other publications.

All contributions are reviewed by at least two consultants who are not provided with author identification.

Form of Manuscript. Authors should submit four neatly typewritten manuscripts in triple spacing with wide margins which should not exceed much more than 25 pages. Each page should be numbered. The first page of two copies should contain the title of the article, name of author/s, highest degree and address or institutional affiliation. The first page of the remaining two copies should contain only the title of the article. The second page of all copies should contain only an abstract ( 100 words) which should be provided in both English and Afrikaans. Afrikaans abstracts will be provided for overseas contributors. All paragraphs should start at the left margin and not be indented.

Major headings, where applicable, should be in the order of METHOD, RESULTS, DISCUSSION, CONCLUSION, ACKNOWLEDGEMENTS and REFERENCES

Tables and Figures should be prepared on separate sheets (one per table/ figure). Figures, graphs and line drawings must be originals, in black ink on good quality white paper. Lettering appearing on these should be uniform and professionally done, bearing in mind that such lettering should be legible after a $50 \%$ reduction in printing. On no account should lettering be typewritten on the illustration. Any explanation or legend should not be included in the illustration but should appear below it. The titles of tables and figures should be concise but explanatory. The title of tables appears above, and of figures below. 'Tables and figures should be numbered in order of appearance (with Arabic numerals). The amount of tabular and illustrative material allowed will be at the discretion of the Editor (usually not more than 6).

References. References should be cited in the text by surname of the author and date, e.g. Van Riper (1971). Where there are more than two authors, et al. after the first author will suffice. The names of all authors should appear in the Reference List. References should be listed alphabetically in triple-spacing at the end of the article. For acceptable abbre viations of names of journals, consult the fourth issue (October) of $D S H$ ABSTRACTS or The World List of Scientific Periodicals. The number of references used should not exceed much more than 20 .

Note the following examples:

Locke, J.L. Clinical Psychology: The Explanation and Treatment of Speech Sound Disorders. J. Speech Hear. Disord., 48, 339-341, 1983. Penrod, J.P. Speech Discrimination Testing. In J. Katz (Ed.) Handbook of Clinical Audiology, 3rd ed., Baltimore: Williams \& Wilkins, 1985.

Van Riper, C. The Nature of Stuttering. Englewood Cliffs, New Jersey: Prentice-Hall, 1971

Proofs: Galley proofs will be sent to the author wherever possible. Corrections other than typographical errors will be charged to the author.

Reprints. 10 reprints without covers will be provided free of charge. All manuscripts and correspondence should be addressed to:

The Editor.

South African Journal of Communication Disorders,

South African Speech and Hearing Association.

P.O. Box 31782, Braamfontein 2017, South Africa.

\section{INLIGTING VIR BYDRAERS}

Die Suid-Afrikaanse Tydskrif vir Kommunikasieafwykings publiseer verslae en artikels oor navorsing, of krities evaluerende artikels oor die teoretiese of terapeutiese aspekte van spraak-, stem-, gehoor- of taalafwykings, of oor aspekte van die prosesse onderliggend aan hierdie afwykings.

Die Suid-Afrikaanse Tydskrif vir Kommunikasieafuykings sal nie mate riaal aanvaar wat reeds elders gepubliseer is, of wat tans deur ander publikasies oorweeg word nie.

Alle bydraes word deur minstens twee konsultante nagegaan wat nie ingelig is oor die identiteit van die skrywer nie.

Formaat van die Manuskrip. Skrywers moet vier netjies getikte manuskripte in 3-spasiëring en met breë kantlyn indien, en dit moet nie veel langer as 25 bladsye wees nie. Elke bladsy moet genommer wees. Op die eerste bladsy van 2 afskrifte moet die titel van die artikel, die naam van die skrywer/s, die hoogste graad behaal en die adres of naam van hulle betrokke instansie verskyn. Op die eerste bladsy van die oorblywende twee afskrifte moet slegs die titel van die artikel verskyn. Die tweede bladsy van alle afskrifte moet slegs 'n opsomming ( 100 woorde) in beide Engels en Afrikaans bevat. Afrikaanse opsommings sal vir buitelandse bydraers voorsien word. Alle paragrawe moet teenaan die linkerkantlyn begin word en moet nie ingekeep word nie.

Hoofopskrifte moet, waar dit van toepassing is, in die volgende volgorde wees: METODE, RESULTATF, BFSPREKING, GFVOLGTREKKING, ERKENNINGS en VERWYSINGS.

Tabelle en Figure moet op afsonderlike bladsye verskyn (een bladsy per tabel/illustrasie). Figure, grafieke en lyntekeninge moet oorspronklike weergawes wees en moet in swart ink op wit papier van 'n hoë gehalte gedoen word.

Letterwerk wat hierop verskyn moet eenvormig wees, professioneel gedoen word en daar moet in gedagte gehou word dat dit leesbaar moet wees na 'n 50\%-verkleining in drukwerk. Letterwerk by die illustrasie moet onder geen omstandighede getik word nie. Verklarings of om- skrywings moet nie in die illustrasie nie, maar daaronder verskyn. Die byskrifte van tabelle moet bo-aan verskyn en dié van figure onderaan. Tabelle en figure moet in die volgorde waarin hulle verskyn, genommer word (met Arabiese syfers). Die hoeveelheid materiaal in die vorm van tabelle en illustrasies wat toegelaat word, word deur die redakteur bepaal (gewoonlik nie meer as 6 nie).

Verwysings. Verwysings in die teks moet voorsien word van die skrywer se van en die datum. bv. Van Riper (1971). Waar daar meer as twee skrywers is, sal et al. na die eerste skrywer voldoende wees. Die name van alle skrywers moet in die Verwysingslys verskyn. Verwysings moet alfabeties in 3-spasiëring aan die einde van die artikel gerangskik word. Vir die aanvaarde afkortings van tydskrifte se titels, raadpleeg die vierde uitgawe (Oktober) van DSH ABSTRACTS of The World List of Scientifir Periodicals. Die getal verwysings wat gebruik is, moet nie veel meer as 20 wees nie.

Let op die volgende voorbeelde:

Locke, J.L. Clinical Phonology: The Explanation and Treatment of Speech Sound Disorders. J. Speech Hear. Disord., 48, 339-341, 1983.

Penrod, J.P. Speech Discrimination Testing. In J. Katz (Ed.) Handbook of Cliniral Audioloßy, 3e ed., Baltimore: Williams \& Wilkins, 1985. Van Riper, C. The Nature of Stuttering. Englewood Cliffs, New Jersey: Prentice Hall, 1971 .

Proewe: Galeiproewe sal waar moontlik aan skrywers gestuur word. Die onkoste van veranderings, behalwe tipografiese foute, sal deur die skrywer self gedra moet word

Herdrukke, 10 herdrukke sonder omslae sal gratis verskaf word.

Alle manuskripte en korrespondensie moet gerig word aan:

Die Redakteur,

Die Suid-Afrikaanse Tydskrif vir Kommunikasieafwykings.

Die Suid-Afrikaanse Vereniging vir Spraak-en Gehoorheelkunde.

Posbus 31782 ,

Braamfontein 2017; Suid-Afrika. 